\title{
Evolution, Factors and Ecological and Socio-Economic Impacts of Ecotourism in Rusizi National Park (Burundi)
}

\author{
Ntiranyibagira Elysée $^{1,2, *}$, Niyondiko Dominique ${ }^{2,3}$, Habonayo Richard ${ }^{1}$, Havyarimana Célestin ${ }^{2}$ \\ ${ }^{1}$ Faculty of Agronomy and Bi-Engineering, University of Burundi, Bujumbura, Burundi \\ ${ }^{2}$ Center for Expertise, Research and Training in Environment and Sustainable Development (CERFED), Bujumbura, Burundi \\ ${ }^{3}$ Faculty of Economics and Management Sciences, University of Burundi, Bujumbura, Burundi
}

Email address:

ebagira2010@yahoo.fr (N. Elysée)

*Corresponding author

\section{To cite this article:}

Ntiranyibagira Elysée, Niyondiko Dominique, Habonayo Richard, Havyarimana Célestin. Evolution, Factors and Ecological and SocioEconomic Impacts of Ecotourism in Rusizi National Park (Burundi). American Journal of Biological and Environmental Statistics. Vol. 7, No. 1, 2021, pp. 29-38. doi: 10.11648/j.ajbes.20210701.14

Received: February 4, 2021; Accepted: February 25, 2021; Published: March 30, 2021

\begin{abstract}
In Africa, conservation policies have been often legitimated by socio-economic arguments that include ecotourism projects in most of protected areas. In Burundi, ecotourism activities started in the 1980s. However, they have never been evaluated to appreciate their contribution to finance conservation and local development. The study carried out in the Rusizi National Park responds to this concern. It aimed to: (i) analyze the evolution of the organization, the pricing strategy and the touristic movement, (ii) analyze the evolution and use of touristic revenues and (iii) analyze the impact of ecotourism on the quality of conservation and local development. The methodology adopted was based on the analysis of data collected from management reports from 1987 to 2015, using performance indicators, SPSS 16.0 for statistical analysis and semi-structured interviews for the validation of the results of data analysis. The results of data analysis showed that the touristic movement is seasonal and evolves following a checkered pattern, with an annual average of 1,683 tourists. They revealed that tourism is statistically foreign reference made to the nationality of tourists and local if we consider the place they come from. They indicated that non-resident foreign tourists come to Burundi for extra-tourism activities. The variability of the touristic movement is linked more to political and security crises and organizational shortcomings than to touristic tariffs which remain derisory since they hardly reach 2,95 US $\$$ for official entrance fees and 2,51 US $\$$ for effective entry fees. The annual touristic revenues are 4,636 US $\$$ average. They represent $71 \%$ of the overall operating income and a tourism royalty collection rate of $41 \%$ that leads to a financial shortfall of 1,919 US $\$$ year. The poor financial performance comes from the lack of financial planning and attractive business plans, insignificant touristic tariffs, weak touristic movement, increase in non-paying staff, illegal tourism by private operators and derisory recovery rates of tourism fees. The low level of touristic income and the return of the almost total amount to the national conservation body for daily operations severely limit self-financing capacities and socio-economic impact of ecotourism on local development. The chronic touristic underperformance is linked to the lack of appropriate touristic investments, infrastructure and marketing, qualified and skillful staff and coherent planning, pricing and recovery policies that lead to amateurish management and sight-seeing navigation. Therefore, there is a great need for better policies, strategies and practices to insure significant improvement of tourism performances
\end{abstract}

Keywords: Rusizi National Park, Ecotourism, Touristic Prices, Touristic Movement, Touristic Income, Impacts of Ecotourism, Conservation, Local Development

\section{Introduction}

In Africa, the post-independence legitimation of the colonial nature conservation policies by socio-economic arguments based on ecotourism and Integrated Conservation and Development Projects [1-5], the concepts of sustainable development and public integration [6] and the more recent concept of Ecosystem Products and Services [7, 8] remains an important challenge, given the unsuccessful results of 
participatory management approaches and tourism activities on the continent $[5,9]$. In Burundi, tourism activity in protected areas began in the second half of the 1980s. Soon, it declined considerably before completely disappearing in almost all protected areas thanks to the long civil war that took place in 1993. The Rusizi national Park, on which relies the study, constitutes a remarkable exception in terms of tourism since it has never experienced a break in touristic movement $[10,9]$. Beyond its biological richness and very remarkable touristic qualities [11-15], its comparative geographical, security and financial advantages, specifically with reference to its proximity to the Capital City Bujumbura from which almost all tourists leave make the most attractive and popular protected area in the country. Given the fact that the development of the touristic potential is one of the ecological conservation goals of the park $[14,10]$ and the fact that no in-depth study has been carried out since the creation of the protected area in 1980 to assess the management of this highly strategic sector for the country's economy, the research is an important contribution to the analysis of the organization, the performance and the efficiency of tourism. The specific goals of the research are: (i) to analyze the evolution of the organization, pricing and touristic movement, (ii) to analyze the evolution of touristic income and its use and (iii) to analyze the impact of ecotourism on conservation and local development. The research is a pioneering study that will provide baseline data for the proactive promotion and sustainable management of ecotourism in Burundian protected areas in general and in Rusizi National Park, in particular.

\section{Methodology}

\subsection{Study Area}

Rusizi National Park is one of the Burundian's 17 protected areas. It is located about ten kilometers in the western part of the City of Bujumbura, the Economic Headquarter of Burundi. It is a Ramsar Site known under number 1180 [16] which is an important transit and wintering route for many species of migratory freshwater birds $[17,18$, 15]. It extends over the Communes of Gihanga in Bubanza Province and Mutimbuzi in Bujumbura Province. It is bounded to the West by the Democratic Republic of Congo, to the South by Lake Tanganika, to the East by National Road 5 and to the North by Buganda Commune in Cibitoke Province. The park covers a total area of 10,673 ha [19] divided between the Palmeraie Sector (6,647 ha), the Delta Sector (1,363 ha), the Corridor of the Great Rusizi (443 ha), the Northern Buffer Zone (2,102 ha) and the Southern Buffer Zone (118 ha) (Figure 1). With an area of approximately 107 $\mathrm{km}^{2}$, the Rusizi National Park falls into the category of major protected areas in the world that particularly interest to Digital Observatory of Protected Areas (DOPA) initiative [20, 21].

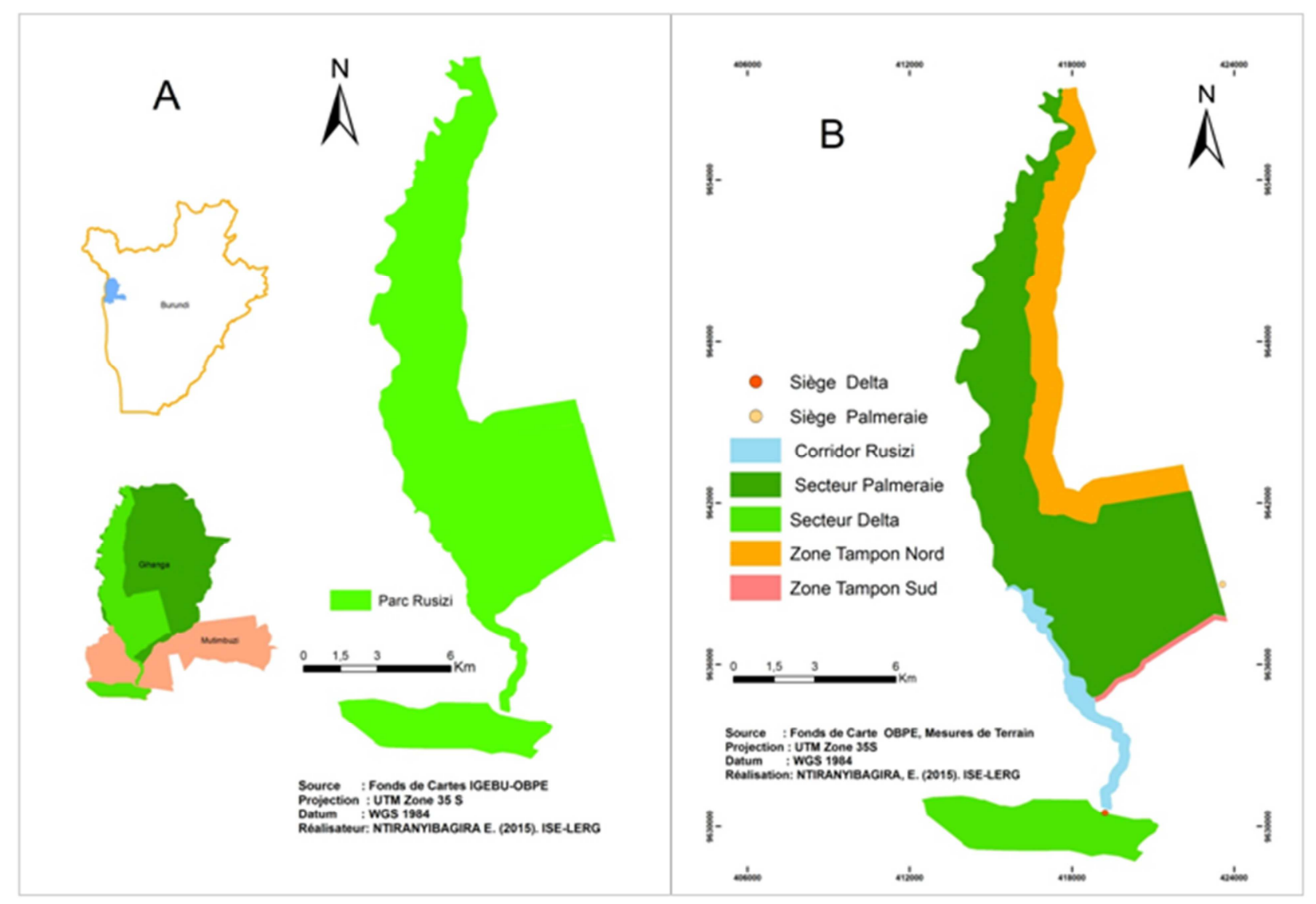

Figure 1. Location and physical configuration of the Rusizi National Park. 


\subsection{Material and Method}

The analysis of touristic activities was based on the exploitation of the park's management reports from 1987 to 2015. It focused on: (1) the touristic infrastructure, organization and marketing, (2) the categories of tourists and their respective numbers, (3) the entry fees and the touristic income, (4) fees collection rates and financial shortfalls and (5) the allocation of touristic income and its socio-economic impact on the participatory management of the protected area Touristic rates varying and differing from one category of tourists to another, we have determined and applied an average annual rate for the calculation of recovery rates and financial shortfalls compared to the entrance fees set by the park's managers. The collection rate annual average ( $T r$ ) was determined by the formula [9

$$
\operatorname{Tr}=\frac{D a}{T m} * 100
$$

where $D a$ and $T m$ represent the average entrance fee and the average touristic tariff expressed in US dollars (US \$), all categories of tourists combined. The average entrance fees $D a$ for a given year were determined by the formula [9]

$$
D a=\frac{1}{N} \frac{R t}{T c}
$$

where $R t$ is the annual touristic income in national currency; the Burundian Franc (BIF), $N$ the annual number of tourists and $T c$ the annual rate of conversion of the US dollar into Burundian Franc. The financial loss or shortfall $M f$ between two years $t_{0}$ and $t_{1}$ between 1987 and 2015 was determined by the relation [9]

$$
M f=\sum_{t=t o}^{t=t 1}[N t .(T m t-D a t)]
$$

average price corresponding to year t and Dat the average entry fee in year t. The results of raw data analysis and preliminary computations were subjected to a thorough statistical analysis using SPSS 16.0. The interest and ability of the protected area to support conservation and boost local or peripheral development were analyzed in terms of income generation capacity and self-financing through ecotourism and natural resource exploitation [22-29].

The results of the different analyses were submitted for a validation process based on semi-structured interviews conducted with park's managers, members of associations involved in the exploitation of natural resources and community representatives.

\section{Findings}

The analysis of the organization, the development and the management of ecotourism showed that ecotourism on tracks, pirogue and mountain biking constitutes the main form of socio-economic development of the park which is made possible by a dense network of traffic tracks, watchtowers or observation posts, beacons and orientation, signage and awareness panels distributed mainly in the Delta sector which is today the most popular and visited sector of the Park of Rusizi (Figure 1).

\subsection{Evolution of Touristic Movement}

The results of analyses of touristic frequentation between 1987 and 2015 showed that it follows a saw-tooth trend (Figures 2, 3). Despite the remarkable recovery in tourism observed from 2005, the touristic peaks of years 1992 and 1993 were never again reached.

where $N t$ is the annual number of tourists of year t, Tmt the

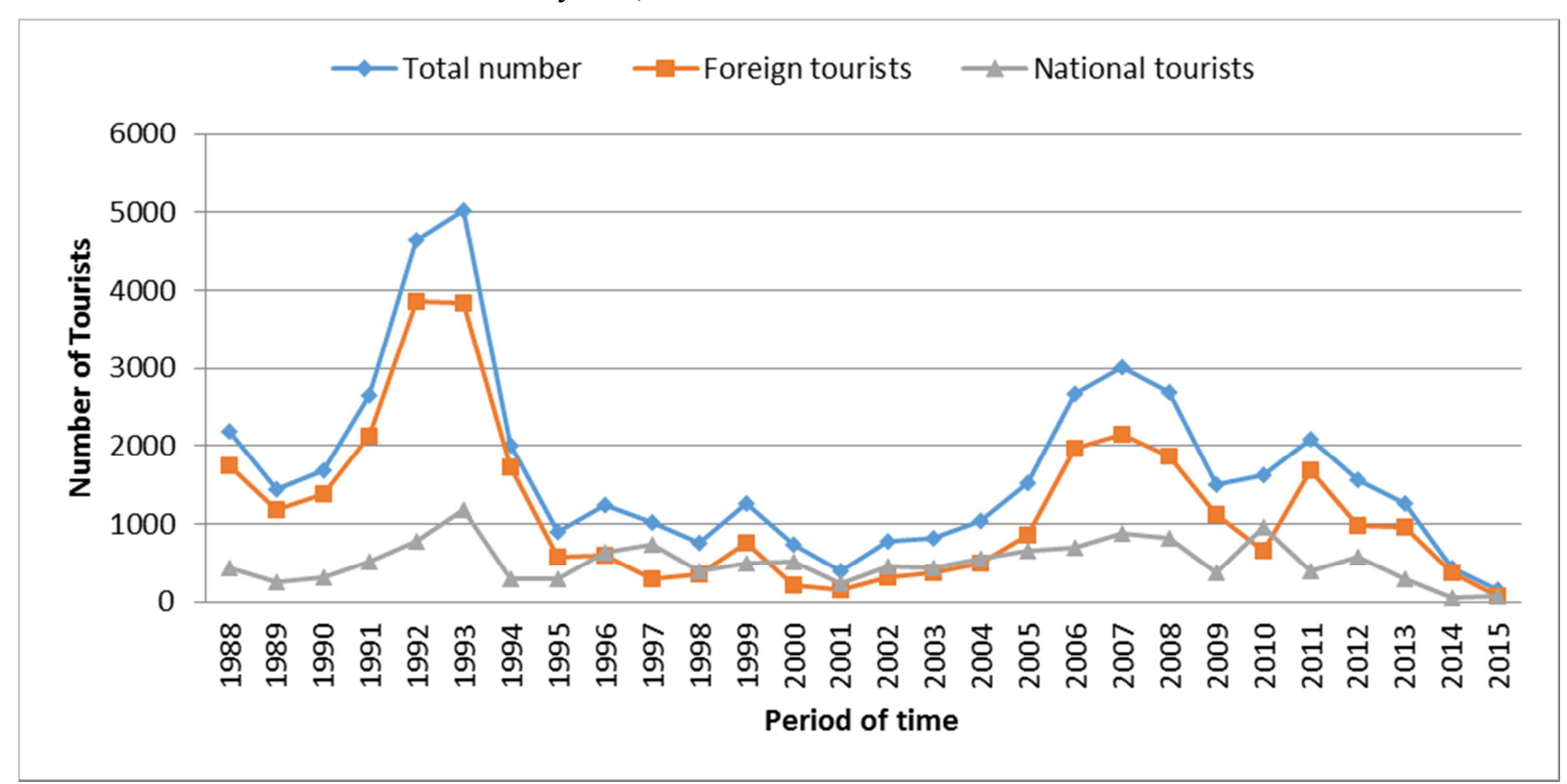

Figure 2. Evolution of the number of tourists according to the nationalities.

Foreign tourists are dominantly of French, Italian, Belgian, German, Dutch and American origins, which in fact constitute the most represented Western Diasporas in Burundi $[9,10]$. The analysis of the variance of the number of tourists 
according to the nationalities showed that there is a highly significant difference in touristic frequentation between foreign and national tourists ( $\mathrm{P}$-value $=0,000 * * *<\alpha=0,05)$ who represent in average $70 \%$ and $30 \%$ of the average annual total that is estimated at 1,683 tourists; that means 1,180 and 503 tourists respectively. It highlights three groups of homogeneous averages of annual tourist numbers. The highest numbers were recorded between 1988 and 1993, the middle numbers between 2005 and 2013 and the lowest numbers between 1994 and 2005. Touristic movement tipped in favor of foreigners before 1996 and after 2005. Between 1995 and 2005, the differences in touristic frequentation between foreign and national citizens are small (Figure 2).

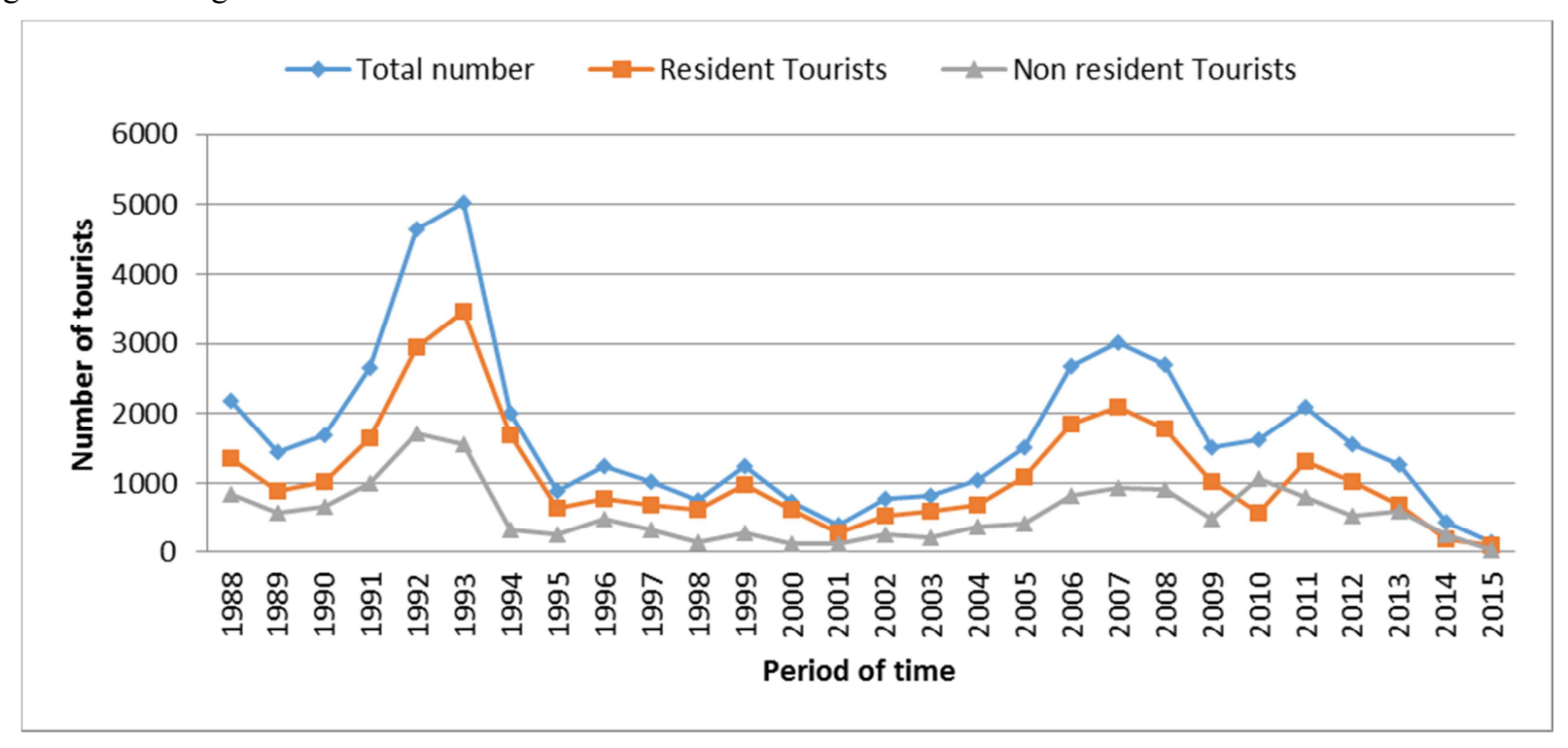

Figure 3. Evolution of the number of tourists according to the geographic origin.

The analysis of the variance of the number of tourists according to the geographic origin showed that there is a very highly significant difference in touristic movement (Pvalue $=0.000 * * * \alpha=0.01$ ) between resident tourists and nonresident tourists who represent in average $66 \%$ and $34 \%$ of the total; that means respectively 1,109 and 574 tourists. It makes it possible to identify three groups of homogeneous averages of annual total numbers of tourists. The highest numbers were recorded between 1988 and 1993, the middle numbers between 2005 and 2013 and the lowest numbers between 1994 and 2005. Touristic frequentation is dominated by residents until 2009 . However, the differences in touristic visits between residents and non-residents are low between 1995 and 2004 (Figure 3).

The analysis of the monthly average number of tourists compared to the general inter-annual average of 141 tourists indicated that the touristic movement is seasonal in nature as it is more important in the dry season than in the rainy season. The seasonal coefficients obtained by the "additive HoltWinters" method showed that the most advantageous months $(\alpha>0)$ or with high tourist activity are May, July, August and October; the months of July and August having the highest average tourist visits with 213 and 190 tourists respectively. The touristic activity of the other months of the year is below the monthly average trend $(\alpha<0)$; the months of November, December and March having the lowest levels of touristic frequentation with 103, 116 and 117 tourists, respectively.

\subsection{Evolution of Touristic Tariffs and Revenues}

The results of touristic pricing analyses showed that touristic tariffs have evolved in three phases for all categories of tourists (Figure 4). We first observed a phase of continuous reduction in tariffs which goes from 1988 to 2008 . Then, there is a considerable and rapid increase in tariffs from 2008 to 2011. Finally, from 2011, a further reduction in tariffs is recorded, which is immediately followed by a stabilization of entry fees at an after all significant level until 2015 (Figure 4).

On average, annual touristic tariffs range from US \$ 0.4 in 2008 to US $\$ 7.9$ in 2011 , with an overall average of US $\$ 2.95$ for an average of effective entry fees of US \$2.51. The price differences between categories of tourists began to be significant from 2011; when they peaked at US \$ 4.0; US $\$ 7.9$ and US \$ 11.9 respectively for nationals, resident and non-resident tourists

Figure 5 showed that touristic revenues evolve according to a polynomial-type regression model of degree 2 with equation $y=30,513 x^{2}-927,96 x+8279,8$ and correlation coefficient $\mathrm{R}^{2}=0.4892$. They decreased from 1988 to 2001 when they reached a minimum of US \$ 286 before rising again until 2014; the maximum cash flow of US \$8,955 having been recorded in 1992. The Kolmogorov-Smirnov test of normality applied to the variables "tourist numbers" and "revenue" showing that their distributions followed a normal distribution (P-value ( $\mathrm{sig})=0.353>\alpha=0.05$ and $\mathrm{P}$-value (sig) $=0.219>\alpha=0.05$ ), the correlation study using the Bravais-Pearson coefficient made it possible to accept the hypothesis of the absence of correlation between these variables ( $\mathrm{P}$-value $(\mathrm{sig})=0.502>\alpha=0.05, \mathrm{r}=0.132)$. This finding showed that there are real difficulties for the financial valorization of the touristic movement and great potential, 
which are nevertheless considerable.

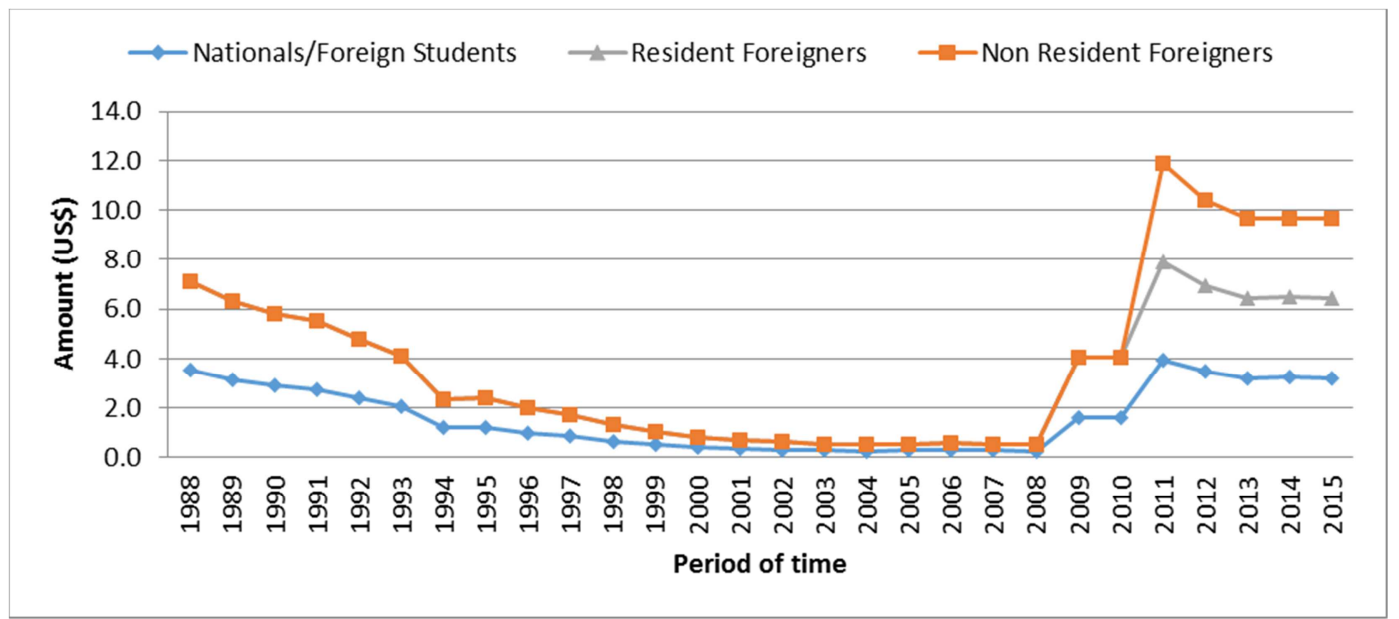

Figure 4. Evolution of touristic tariffs according to tourist categories.

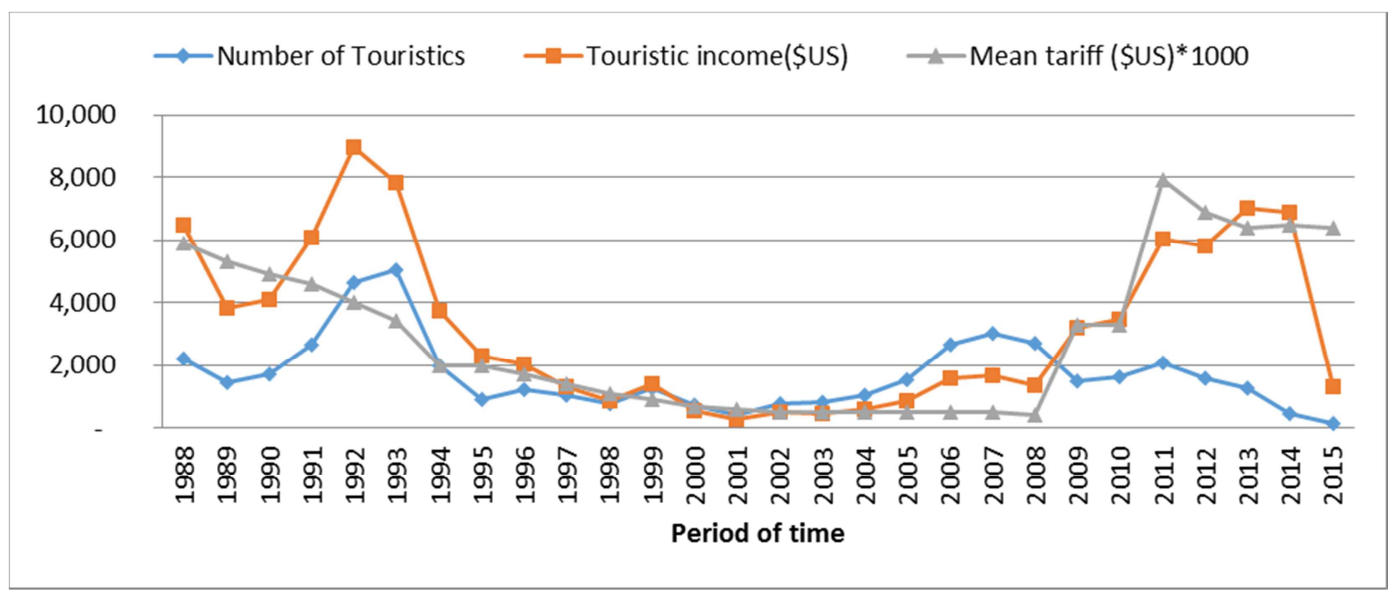

Figure 5. Evolution of the main touristic variables from 1988 to 2015.

If we include the rental costs of the canoe and mountain bike acquired in March 2010 from the Decentralized Cooperation of the Pays de la Loire Region (France) in tourist revenue, the park's average annual touristic revenue reaches US $\$ 4,801$ over the entire study period (Figure 6).
Ultimately, the average total annual revenue of the park peaks at US $\$ 6,555$ which is split between the exploitation of natural resources for US \$1,919 (29.3\%) and the touristic exploitation for US \$4,636 (70,7\%).

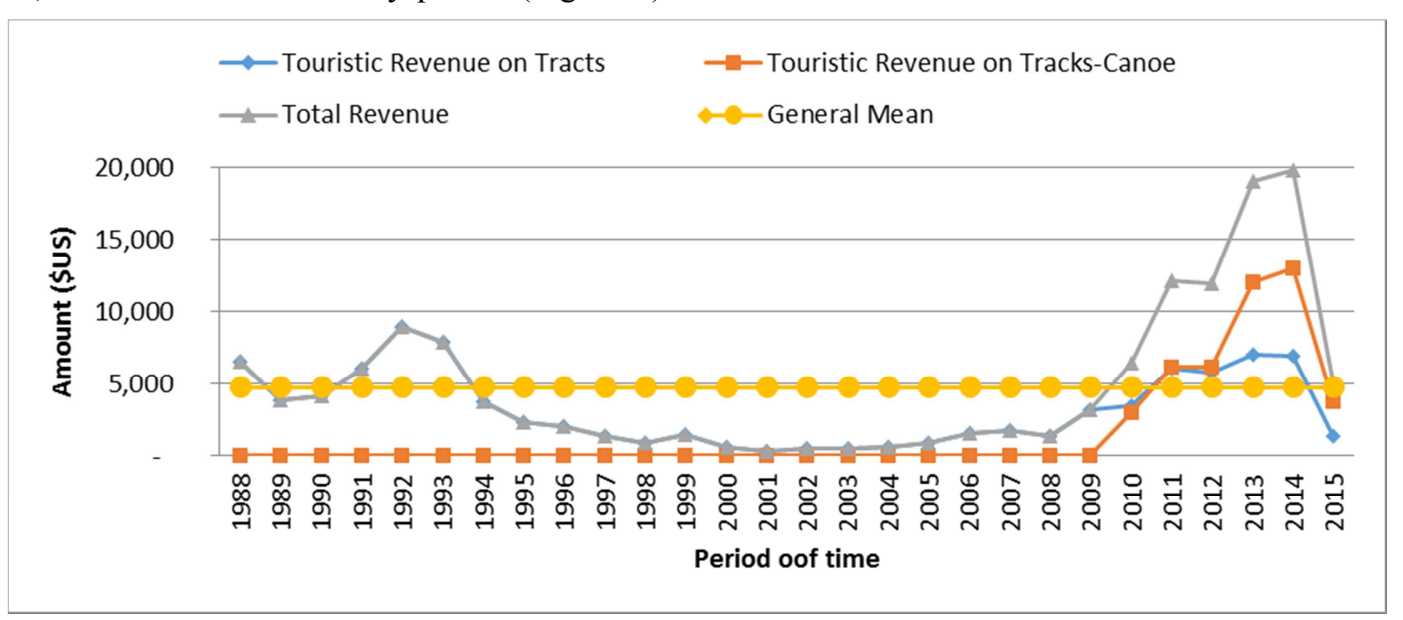

Figure 6. Comparative evolution of touristic revenues on Tracks and Canoe.

The comparative analysis of touristic tariffs and average annual effective entrance fees showed positive and negative 
abnormalities in the collection of touristic fees (Figure 7). The results of analyzes revealed that negative abnormalities or underpayments have been observed between 1988 and 1994 on one hand and between 2008 and 2013 on the other hand. Conversely, they indicated a positive abnormality between 2013 and 2015.

Between these years with contrasting abnormalities, there is a period of full fees recovery which extends from 1994 to
2008 and which corresponds broadly to the period of the civil war that started in 1993 (Figure 7). The overall financial shortfall for the period from 1988 to 2015, which is calculated according to the formula (3), reaches a total amount of US $\$ 53,742$ that corresponds to a mean annual loss of US $\$ 1,919$ for an average annual tracks revenue of US $\$ 3,231$; which corresponds to a low recovery rate of around $41 \%$.

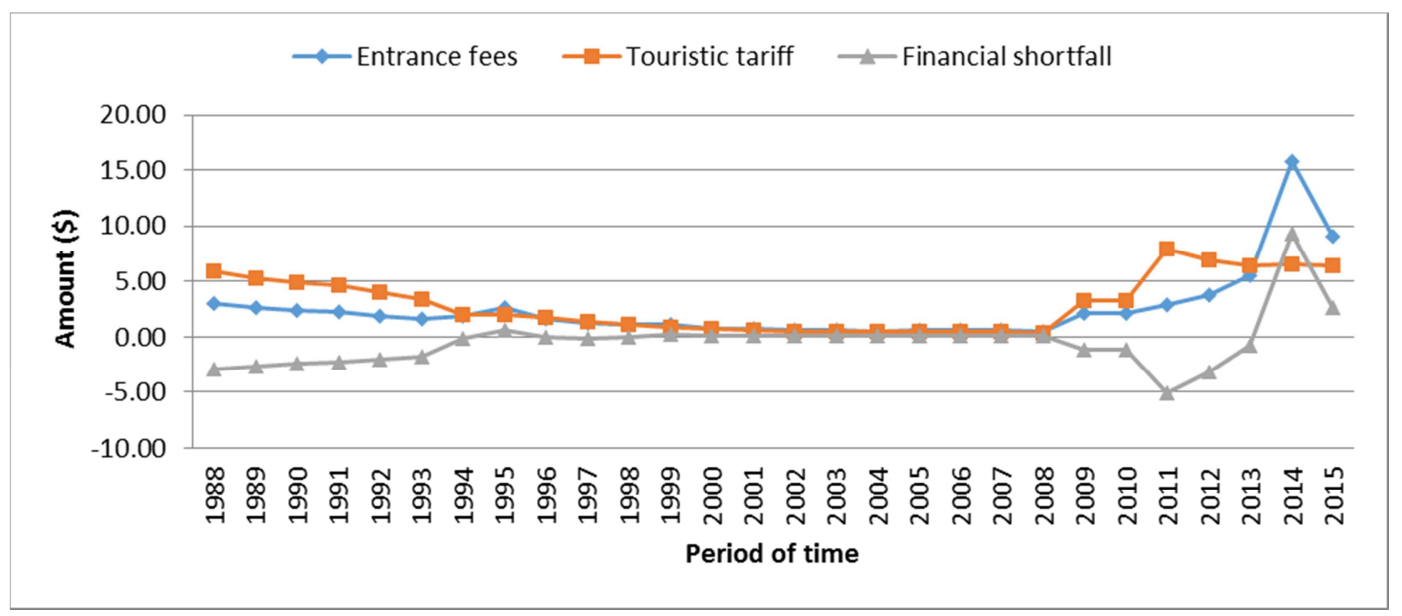

Figure 7. Comparative evolution of touristic tariffs and entrance fees.

\subsection{Allocation and Socio-economic Impact of Touristic Revenues}

The touristic revenues from the Rusizi national Park, like those from other protected areas which still benefit from a minimal level of tourism such as the Natural Monuments of the East (Faille des Allemands de Nyakazu, Chutes de la Karera) are paid in large part to the accounts of the Burundian Board for Environment Protection (OBPE). This one often redistributes the touristic revenues for operating purposes. The results of the interviews with the managers indicated that the part of the revenue that remains at the Park is used for its day-to-day operations. On rare occasions, deadwood women collectors are paid out of this modest portion of the proceeds for maintenance works on touristic infrastructures. These results showed that the direct socioeconomic impact of touristic activities and revenues on peripheral populations is negligible, if not null.

\section{Discussion of the Findings}

\subsection{Touristic Tariffs and Movement}

The touristic movement followed a saw tooth trend (Figures 2,3) which can be explained more by socio-political and security situations than by touristic tariffs. Indeed, with an mean tariff of US $\$ 2.95$ per tourist, entrance fees remain insignificant (Figure 4) compared to those of countries in the East African sub-region where vision fees sometimes reach several hundred of US dollars, not including other expenses related to the stay $[30,31]$. The reduction in touristic tariffs decided in times of political crisis to stimulate tourism, especially after the civil war in 1993, is ineffective for the development of the sector because tariffs are still too low to influence touristic frequentation, which does not exceed 1,683 tourists per year, average; a figure which is close to previous estimates established at 1,500 tourists per year [15].

The proof is that the largest numbers of tourists were recorded in times of peace and stability (1988-1993, 20052013) and the lowest numbers in periods of civil war (19942004) and/or economic embargo (1996-1999) (Figures 2, 3), due to the departure of expatriates and the insecurity that prevailed in the park, often transformed into a rebel breeding ground and a field of armed conflicts. Likewise, the negative trend in touristic movement observed from 2013 can be explained by the appearance of precursor signs of the sociopolitical crisis that has hit the Burundi since April 2015.

In reality, the high variations in touristic tariffs in US $\$$ (Figure 4) are due to the effects of the devaluation of the Burundian franc which is the currency used for pricing and payment of entrance fees until recently, even for foreigners [9]. They are also linked to the lack of harmonization of touristic tariffs since each protected area appreciates and sets its tariffs at will, while law ${ }^{\circ} 100 / 007$ of January, $25^{\text {th }} 2000$ specifies that every visit to protected areas is subject to prior payment of a head tax of which the amount is set by the national conservation body [15].

In terms of touristic movement, Rusizi national Park is the only protected area in Burundi where no disruption has been observed since the start of tourism in protected areas and the record numbers reported in 1992 and 1993. The statistical analysis of the number of tourists showed that in terms of nationality, the majority of tourists are foreigners, while in terms of origin, they are residents. 
The difference between the numbers of foreign and domestic tourists is greater in times of socio-political stability than in times of crisis, which can be explained by the departure of expatriates precisely in times of political turbulence. On the other hand, the interannual variability of the number of national tourists is relatively low, compared to that of foreign tourists, even if we observe a depletion of tourism in a period of crisis (Figure 2). In general, the general trends in touristic frequentation are similar if we compare the trends by nationality and origin (Figures 2,3 ).

Ultimately, therefore, tourism in Rusizi national Park is fundamentally foreign due to the nationality of the majority of tourists. Otherwise, it is national or local in terms of geographical origin. Moreover, foreign tourists, whether foreign or Burundian by nationality, come to Burundi for official, commercial, expert and research missions or for family visits for members of the Burundian diasporas, worldwide

They only sightsee the park on a secondary and occasional basis, often in the company of friends or acquaintances of the place that usually do not pay for entrance fees. Thus, with reference to the definition of a tourist by the World Bank, there is practically no tourism in Burundi in general and in Rusizi national Park in particular.

Like the countries of the East African sub-region, sight tourism is fundamentally based on the observation of wild fauna [2], in this case that of hippos (Hippopotamus amphibius), crocodiles (Crocodilus niloticus) and migratory birds of various species whose populations are declining due to the habitat destruction, the reduction of grazing areas and deteriorating climatic conditions, as some previous studies have shown [32, 33]. This considered, the advanced degradation of the Rusizi national Park constitutes a serious threat to ecotourism [9].

Indeed, the great and strong dependence of local populations on the direct exploitation of natural resources of the park [32, 34, 33, 19] and the increasing pressures of peripheral exploitation [9] induce a considerable degradation of the protected area and a remarkable decline in animal populations that fuel the tourist movement $[33,9]$.

In addition, the absence of controlled fire practices as a central element in the management and regeneration of habitats in the ecology of tropical ecosystems [35], in particular for the renewal of interior pastures for wildlife and the prevention of periodical criminal bushfires also contribute to the deterioration of the touristic movement as it often leads to outings and killings of wild animals such as Hippopotamus amphibius which devastate village crops.

\subsection{Evolution of Touristic Revenue}

Annual touristic revenues are still insignificant due to the low level of touristic movement, insignificant entry fees and recurring touristic under-recoveries (Figures 5, 6, 7). The low rate of touristic recovery of $41 \%$ and the significant annual mean shortfall of US \$1,919 for all tourists (Figure 7) constitute a serious limitation for touristic financial performance, in comparison with that of technical structures of the countries of the East African sub-region such as Rwanda, Tanzania, Kenya and Uganda [30, 36, 31]. It reflects a complacent management of touristic activity since the law imposes compulsory payment of an entry tax by all visitors [10].

The increase in touristic revenues observed since 2005 (Figures 5,6) is only due to the gradual increase in touristic fees which increased in 2009 (Figure 4), given the fact that the number of tourists decreased after that year (Figures 2, 3).

The lack of correlation between the touristic revenues and the number of tourists and the low recovery rate confirm the hypothesis of a structural underpayment of entrance fees which is attested by the results of interviews with park's staff. This situation is justified by many factors including numerous free school and academic visits, non-tariff payments, complacent exemptions from payment and nonregistration of some payments.

The negative abnormalities or underpayments observed would be dictated by a concern to promote tourism in the beginning of ecotourism (1988-1994) and the resumption of touristic activity in 2008, after a touristic dormant phase and by administrative mismanagement (Figure 7). The positive abnormality could be explained by the speculative surcharges imposed to tourists who are not or poorly informed about updated touristic tariffs, especially since these ones are still too low to have a significant impact on the touristists' portfolio (Figure 7).

The important and sometimes unjustified increase of nonpaying tourists and the low level of the collection of entrance fees constitute a recurring problem which weakens the park's cash flow and reduces its self-financing capacities, given the fact that full collection only takes place in times of crisis when touristic tariffs and movement are at their lowest levels (Figures 2, 3, 4, 7).

Also, the existence of illegal tourism by certain private operators and the lack of national coordination that generates overlaps between the Burundian Board for Environment Protection (OBPE) and the National Tourism Board (ONT) through which tourists and foreign delegations members come in have a negative impact on the development of the sector. While the tourism sector is administratively managed by ONT, ecotourism in protected areas is managed by OBPE that sets tariffs and manages touristic revenues. In practice, these state structures maintain conflicts of interest and competences which are at the origin of numerous overlaps and significant financial shortfalls linked to unpaid touristic visits often organized by ONT in certain protected areas, in favor of foreign personalities who often come to Burundi for work missions.

The highly beneficial effect of the Canoe and Mountain Bike touristic offer on touristic revenues since 2010 highlights the enormous touristic potential of the protected area (Figure 6). It showed that the touristic business actually suffers from the lack of competitive touristic investments and facilities, well-trained tour guides, touristic marketing and an appropriate touristic planning and pricing policy. 


\subsection{Socio-economic and Ecological Benefits of Ecotourism}

Ultimately, the low level of touristic revenues and resource exploitation, which do not exceed US \$4,636 and US $\$ 1,919$, respectively; i.e. $71 \%$ and $29 \%$ of the total revenue and the relatively large weight of illicit exploitation revenues in non-touristic revenues $(61 \%)$, showed that participatory management of the park has serious limits which do not allow it to boost a dynamic of self-financing, nor to generate significant socio-economic benefits for the sustainable management of the protected area.

Indeed, as a recent study on the management efficiency of Burundian's protected areas clarified, the socio-economic benefits of the touristic and non-touristic exploitation of the Rusizi national Park are anecdotal [15].

This result is confirmed by the conclusions of other studies which have shown that most of the local communities involved in ecotourism projects would perceive only a small part of the benefits generated and would depend only on other activities which are sometimes very predatory for their livelihood [37, 4, 38, 39, 31].

The constraint of the low level of touristic and nontouristic revenues is accentuated by the retrocession of most of the revenue to the central administration for its day-today operations. It does not allow the protected area to finance income-generating activities or create local jobs for local populations as a means of participatory management [28].

This financial weakness, which is one of the main causes of ineffectiveness of conservation policies in Central Africa [40] resulting from the lack of financial planning embedded in business plans that are essential for the mobilization of external financing and self-financing [41] and the structural, strategic and operational challenges of tourism driven by contradictory interests [42], is nevertheless common to many protected areas around the world [38].

However, with a touristic annual mean of more than 1,650 tourists, Rusizi national Park constitutes the only protected area in Burundi whose touristic revenues could cover most of the current operating needs and improve the quality of conservation, apart from staff salaries which are covered by the state subsidies through the national conservation body OBPE

\section{Conclusion}

The study of the management of touristic activity in Rusizi national Park has clearly shown that the enormous touristic potential of the protected area is far from being effectively and profitably exploited. The results of the analyses revealed the existence of structural and chronic underperformances that are fed by the inadequacy of policies and the ineffectiveness of planning, marketing and supervision activities in tourism. The touristic performance and the management of touristic revenues do not yet improve the quality of conservation and stimulate significant local development. The main factors which limit the realization of the touristic potential of the protected area are the glaring overlaps and conflicts of administrative powers, a lack of touristic planning and marketing, the insufficiency of qualified management staff, low touristic tariffs, a derisory recovery rate and inconsistent touristic income. In addition, the legal and administrative obligation for managers of protected areas to transfer the revenues from touristic and natural resource exploitation to the bank accounts of the national conservation body does little to encourage local initiatives and efforts to rationalize touristic exploitation and management. In general, Rusizi national Park is characterized by a non professional management that is carried by sight navigation and a glaring lack of validated work tools, trials and errors and improvisations that unable the visibility, the mobilization of funding, the achievement of conservation goals and the assessment of management effectiveness. Additionally to these structural and organizational shortcomings, political crises and instability have considerably reduced touristic attraction of the protected area. Ultimately, Burundi should develop and adopt a clear and effective strategic and operational line that integrates the conservation and touristic sectors into a single national structure, to boost touristic and the national economy, as well.

\section{References}

[1] Rodary E. (2001). Les espaces naturels: l'aménagement par la participation? Mise en réseau et territorialisation des politiques de conservation de la faune en Zambie et au Zimbabwe. Thèse de Doctorat, Université d'Orléans, France, $531 \mathrm{p}$.

[2] Colchester M. (2003). Nature sauvage, nature sauvée? Peuples autochtones, aires protégées et conservation de la biodiversité. Mouvement mondial pour les forêts tropicales, (WRM) et Fonds mondial pour la nature (WWF), 154p

[3] Rodary E., Castellanet C. et Rossi G. (dir.) (2003). Conservation de la nature et développement. L'intégration impossible? Paris, GRET, Karthala, 308p.

[4] Nicholls H. (2004). The Conservation Business, PLoS Biology, Vol. 2 (9): 1256-1259.

[5] Binot A. (2010). La Conservation de la Nature en Afrique Centrale. Entre Théories et Pratiques. Des Espaces Protégés à Géométrie Variable. Thèse de Doctorat, Université Paris 1 Panthéon-Sorbonne, $444 \mathrm{p}$.

[6] UICN, PNUE et WWF (1980). Stratégie Mondiale de la Conservation. La conservation des ressources vivantes pour le développement durable, Gland, UICN, 64p.

[7] MEA (2005). Rapport de synthèse de l'Evaluation des Ecosystèmes pour le Millénaire. Millenium Ecosystem Assessment, 59p.

[8] TEEB (2010) L’Économie des écosystèmes et de la biodiversité: intégration de l'économie de la nature. Une synthèse de l'approche, des conclusions et des recommandations de la TEEB, www.unep.org/pdf/TEEB_FR.pdf. consulté le 15/02/2016. 
[9] Ntiranyibagira E. (2017). Dynamiques d'occupation du sol, tendances évolutives globales et facteurs d'evolution des aires protégées. Etude diachronique du Parc national périurbain de la Rusizi (Burundi) de 1984 a 2015. Thèse de Doctorat Unique en Sciences de l'Environnement, Université Cheikh Anta Diop de Dakar (Senegal), 340p.

[10] Nindorera D., Hakizimana F. et Nzigidahera B. (2000): 20 ans d'existence de la Réserve Naturelle de la Rusizi (1980-2000), INECN, 35p.

[11] Reekmans M. (1980). La végétation de la plaine de la basse Rusizi (Burundi). Bulletin du Jardin Botanique Belge, 50: 401-444.

[12] Gisabwamana G. (1995). Contribution à l'étude écologique du secteur Palmeraie de la Rusizi: analyse de la flore et de la faune. Mémoire de fin d'Etudes. Université du Burundi, Institut Supérieur d'Agriculture, 75p + Annexes

[13] Hakizimana F. (1995). Contribution à l'étude écologique du Delta de la Rusizi: analyse de la physionomie végétale et de la faune. Mémoire de fin d'Etudes. Université du Burundi, Institut Supérieur d'Agriculture, 68p + Annexes.

[14] Wakana M. et Debonnet G. (1996). Parc National de la Rusizi: Plan de Gestion. Projet d'appui à la protection des ressources naturelles (APRN). GTZ/INECN, 99p + Annexes.

[15] UICN-PACO (2011). Parcs et réserves du Burundi: évaluation de l'efficacité de gestion des aires protégées. UICN/PACO, Ouagadougou, Burkina Faso, 107p.

[16] Bukuru J. M et Rufuguta E. (2013). Fiche descriptive sur les zones humides Ramsar (FDR)- Parc National de la Rusizi. Version 2009-2014, 13p.

[17] Ntakimazi G., Nzigidahera B., Nicayenzi F. et West K. (2000). L'état de la diversité biologique dans les milieux aquatiques et terrestres du Delta de la Rusizi. Projet de lutte contre la pollution et autres mesures visant à protéger la biodiversité du Lac Tanganyika (RAF/92/G32), UNDP-GEF. $51 \mathrm{p}+$ Annexes.

[18] Ntakimazi G. et Nzigidahera B. (1999). Le secteur Delta du Parc national de la Rusizi: conditions écologiques, flore et faune, $48 \mathrm{p}$.

[19] Cayate M. L. et Kakunze A. C. (2015). Plan de gestion du Parc National de la Rusizi. Office Burundais pour la Protection de l'Environnement, 120 p+ Annexes.

[20] Chape S., Blyth S., Fish L., Fox P. and Spalding M. (compilers) (2003). 2003 United Nations List of Protected Areas. IUCN, Gland, Switzerland and Cambridge, UK and UNEP-WCMC, Cambridge, UK. ix $+44 p$.

[21] Dubois G., Bastin L., Martinez Lopez J. and al. (2015). The Digital Observatory for Protected Areas (DOPA) Explorer 1.0. Report EUR 27162 EN, European Commission, Joint Research Centre, Institute for Environment and Sustainability, $60 \mathrm{p}$.

http://publications.jrc.ec.europa.eu/repository/bitstream/JRC9 5295/lb-na-27162-en-n\%20.pdf consulté le 22 mai 2016.

[22] James A. N (1999). Institutional constraints on protected area funding. Parks, 9 (2): 15-26.

[23] Balmford A., Bruner A., Cooper P. and al. (2002). Economic reasons for conserving wild nature, Science, 297, 950-953, DOI: $10.1126 /$ science. 1073947.
[24] Dumoulin D. K. et Rodary E. (2005). Les ONG, au centre du secteur mondial de la conservation de la biodiversité. In Aubertin C. (éd.): Représenter la nature ? ONG et biodiversité, Paris, IRD Éditions: pp 59-98.

[25] Emerton L., Bishop J. and Thomas L. (2006). Sustainable Financing of Protected Areas. A global review of challenges and options. Best Practice Protected Area Guidelines Series No. 13. IUCN: Gland, Switzerland and Cambridge UK, 109p. DOI: $10.1046 /$ j.1523-1739.2000.99325.x.

[26] Koontz A. (2008). The Conservation Marketing Equation. A manual for conservation and development professionals, Enterprise Works/VITA, USAID, 44p.

[27] Manuel B. et Doumenge C. (2008). Entre marginalisation et démagogie: quelle place reste-t-il pour les communautés locales dans les aires protégées ? Les Cahiers d'Outre-Mer [En ligne], $244 \mid$ 2008, mis en ligne le 01 octobre 2011, consulté le 01 décembre 2012. URL: http://com.revues.org/5476; DOI: 10.4000/com.5476, p 459488.

[28] Granier L. (2009). Participation des populations locales à la gestion des aires protégées et contribution à la lutte contre la pauvreté: de nouvelles solutions juridiques, http://www.ecocy.net/fr/journal.php?actu=29 consulté le $15 / 03 / 2015,3 p$

[29] Bonnin M. et Rodary E. (2012). L'influence des services écosystémiques sur les aires protégées: premiers éléments de réflexion. Programme Serena, Document de travail $n^{\circ} 2012-$ $02,17 \mathrm{p}$

[30] Rwanyiziri G. (2009). Géopolitique de l'environnement au Rwanda. Pour une gouvernance participative des espaces protégés. Geography, Université de Pau et des Pays de l'Adour (France). Thèse de Doctorat, 477p. HAL Id: tel-00449865 https://tel.archives-ouvertes.fr/tel-00449865.

[31] Doumenge C., Palla F., Scholte P., Hiol F. et Larzillière A. (2015). Aires protégées d'Afrique centrale - État 2015. OFAC, Kinshasa, République Démocratique du Congo et Yaoundé, Cameroun, $256 \mathrm{p}$.

[32] Nzigidahera B. (2003). Etude d'évaluation des impacts des actions anthropiques et du degré de disparition de la biodiversite: Proposition de Plan de gestion de la Réserve Naturelle de la Rusizi, Réserve de Biosphère en projet. INECN, UNESCO-MAB, 59p.

[33] Polisi A. (2010). Gestion de la Réserve naturelle de la Rusizi au Burundi. Problématique des activités anthropiques et du déclin des populations animales. Mémoire de Master en Sciences de l'Environnement. Université de Liège, Campus d'Arlon, 63p.

[34] Nzigidahera B. (2008). Etude de base pour la Réhabilitation de la Réserve Naturelle de la Rusizi. Programme Transitoire de Reconstruction Post Conflit (PTRPC) au Burundi, 98p.

[35] Hardesty J., Myers R. and Fulks W. (2005). Fire, Ecosystems and People: A Preliminary Assessment of Fire as a Global Conservation Issue. In: The George Wright Forum. 22 (4): 78 87.

[36] UICN (2014). Nouvelles des Aires Protégées en Afrique $n^{\circ} 74$

[37] Oates J. F. (1999). Myth and reality in the rain forest: how conservation strategies are failing in West Africa. University of California Press, Berkely, CA, xxviii, 310 pp. 
[38] Dumoulin D. K. (2005). Les politiques de conservation de la nature en Amérique latine: au cœur de l'internationalisation et de la convergence des ordres politiques, IUED-NCCR NorthSouth (Genève) et CREDAL (Paris), REVISTA DE LA CEPAL • Numéro Spécial: 71-85.

[39] Aubertin C. et Rodary E. (2008). Aires protégées, espaces durables? IRD, 276p.

[40] Guéneau S. et Franck J. (2004). Conservation de la biodiversité forestière tropicale en Afrique centrale: dépassionner les débats. Institut du développement durable et des relations internationales. Idées pour le débat $n^{\circ} 14 / 2005$ | Ressources naturelles, $11 \mathrm{p}$.
[41] Landreau B. (2012). Guide pour l'élaboration des Plans d'Affaires simplifiés pour les Aires Protégées. Fédération Internationale du Banc d'Arquin (FIBA). Agence Française pour le Développement (AFD), Fonds Français pour l'Environnement Mondial, 61p.

[42] Tardif G. (1999). Mesures à privilégier en bordure des aires protégées au Québec pour contribuer à l'atteinte de leurs objectifs. Gouvernement du Québec, Ministère des Ressources naturelles, Rapport d'Expertise, 113p. 